\title{
Research on the Deep Integration of Information Technology and Ideological and Political Education Teaching
}

\author{
Li Tao \\ Baicheng Normal University, Baicheng, Jilin, 137000, China \\ Email: bcsfxylitao@163.com
}

Keywords: Information Technology, Ideological and Political Education, Teaching Research

\begin{abstract}
In order to deepen the application of information technology in ideological and political education, we should innovate teaching ideas, teaching models and learning methods. It is the main work of creative idea and practical exploration in ideological and political education to focus on the high integration of information technology and ideological and political courses, taking the implementation of application as the basic starting point. Under this condition, this paper will focus on the development and sharing of informational educational resources based on network, and focus on the research of teaching mode in the new era.
\end{abstract}

\section{Introduction}

The integration of modern information technology and teaching means of higher education is the strategic demand and the general trend of education development in China at present, and it is also the trend of education in the world. As early as 2012, the Ministry of Education pointed out that information technology and educational teaching are important concepts in the future education development in ten-years Development Plan of Educational Informatization[1]. At present, many colleges and universities in China are actively developing the integration of ideological and political education and information technology, the more common means is multimedia teaching, that is, multimedia teaching in the classroom or multimedia network teaching methods. It can be made clear that modern information technology has shown great advantages and positive effects in ideological and political education teaching, which also proves that the integration of information technology and modern education and teaching is a feasible way. At the end of 2016, at the National University undefined s Ideological and Political Work Conference, General secretary Xi Jinping emphasized the importance of using network information technology and new media technology to make the work alive, thus promoting the deep integration of traditional advantages of ideological and political work with the information technology, and enhancing the sense of time and appeal. Under the guidance of general secretary Xi Jinping important speech, great progress has been made in the practice and exploration of information technology and ideological and political teaching in colleges and universities in our country, which provides a clear direction for the reform of the teaching mode of ideological and political education in colleges and universities.

\section{Basic Logic of Integration of Information Technology and Ideological and Political Education and Teaching}

From the perspective of the application of information technology in the development of education, the basic logic of the integration of information technology and education and teaching, and the implementation of education and teaching activities, is mainly reflected in these three aspects.

\subsection{Educational Opening Movement and Mass Teaching Mode Based on Media.}

The popularization of the openness of educational activities and large-scale teaching activities with the media as the main means of communication have brought a strong driving force to the deep integration of information technology and ideological and political education and teaching. The 
reform of education system and the innovation of teaching mode have been accelerated with the development of worldwide open teaching and resource movement[2]. The large-scale online education course (MOOC) provides a huge amount of free learning resources, and at the same time, it fully emphasizes the idea of the audience participating in the teaching activities, the core of which is "learning", that is, "students learning". The important change is the transfer of teacher-dominated classroom teaching model to student-centered classroom teaching mode, and the structure and role of teaching activities have changed to a certain extent. The emergence of large-scale online education courses also gives confidence and driving force to the deep integration of information technology and ideological and political education in colleges and universities. In 2014, the main course of ideological and political education, "ideological and moral cultivation and legal basis", was officially launched in China online education interactive platform-the wisdom tree. The course is under the overall responsibility of Fudan University. More than 20 teachers from more than 10 universities in China, headed by Peking University, are involved in the construction of the course, which is also the first large-scale online ideological and political education course in China. That opened a large-scale online course in the field of ideological and political education in China practical application. In September of the same year, the course "introduction to the basic principles of Marxism" set up by Tsinghua University was launched on the same platform. Soon after, ideological and political education courses of Wuhan University were also launched at the same time.

\subsection{Characteristics and Dissemination Modes of Information Technology.}

The characteristics and communication mode of modern information technology are basically consistent with the psychological characteristics and growth track of college students, which provides a new development idea and development space for the deep integration of ideological and political education and information technology. The psychological environment of college students growing up in the information age is consistent with the environment of the network, which is an important basis for the establishment of a new space for the development of ideological and political education in colleges and universities. On the basis of this, this new space should meet the main demand of students individualized expression, and make use of the tools such as Weibo and WeChat, represented by modern information technology, as a means of "stickiness" between college students and students and create a new space for ideological and political education[3]. Contemporary college students are witnesses and users of Internet technology progress, they are keen to accept the new things, and always maintain a strong enthusiasm for the new and challenging things in the field of information technology. From this point of view, its nature is no different from that of modern information technology, which is also the guarantee for the development of ideological and political education and teaching in colleges and universities.

\subsection{Information Technology and the Birth of New Education Industry.}

On the basis of information technology, a number of new educational industries have emerged, represented by this new educational industry, whose learning environment and learning methods promote the innovation and reform of educational and teaching methods, that provides theoretical basis and practical guidance for the deep integration of information technology and ideological and political education and teaching[4]. In recent years, the online education model, led by large-scale online courses, has been welcomed by all circles of education, which is also a successful case of the reform of traditional teaching mode by information technology. Taking Tsinghua University as an example, in the course of "introduction to the basic principles of Marxism", the syllabus is taken as the basis, and then it is subdivided into several units and sequences, each of which is composed of several video teaching contents, taking students course notes and online assignments as a means of assessing grades and credits. According to relevant statistics, there are more than 1,000 students in the school to participate in online courses, and more than 10,000 outside the school also participated in the online teaching. Through this kind of large-scale online course as the teaching means, it can reverse the malpractice of the traditional teaching mode, give play to the students subjective initiative in the study. Encouraged by similar practices, Tsinghua University has dropped out of 
other large online ideological and political education courses since 2015.

\section{Exploration and Research on the Deep Integration of Information Technology and Ideological and Political Education and Teaching}

Large-scale online education teaching course is a classic successful case in which information technology and teaching activities are deeply integrated. Since 2013, colleges and universities in our country have introduced this teaching model one after another. After several years of development and precipitation, it has become a more common and mature teaching mode in colleges and universities. However, from the actual situation, there are some problems in the application of online teaching courses to the teaching activities in colleges and universities. At present, there are not many online educational platforms developed independently in China, among which ideological and political courses are few. Fudan University, as the initiator of online ideological and political course education, and Tsinghua University, which is more advanced in the construction of online ideological and political curriculum education, have more mature teaching experience of deep integration of information technology and ideological and political education. In this paper, the author summarizes the advantages and disadvantages of online ideological and political education with the help of relevant investigation materials and interviews, combined with the practical results of the large-scale online ideological and political education curriculum carried out in these two schools[5]. From the data collected, on the basis of the question of "the most attractive characteristics of the large-scale online ideological and political education course", most students rated the "free learning time and unfettered learning space" as the highest. These aspects, such as fresh learning style, high-quality teaching content and interesting curriculum design, are also highly rated. In contrast, the "interactive feedback exchange" aspect is not universally accepted by students.

Secondly, based on the question of "what problems still exist in large-scale online ideological and political education", the vast majority of students agree that "there is a lack of effective learning supervision measures", while "learning atmosphere is relatively weak", "problem feedback is short of immediacy," Some students also pay attention to some problems, such as "technical immaturity" and "language barrier". From the aspect of "problem feedback is short of immediacy" of student feedback, it may be the main reason that "interactive feedback communication" is not widely accepted.

Furthermore, on the question of "what are the extensible suggestions and opinions for large-scale online ideological and political education", students generally think that the teacher-student interaction in large-scale online ideological and political education courses should be strengthened, and some students think that it is necessary to optimize teaching platform, improve teaching equipment and facilities, and establish a strict assessment system, and a small number of students have discussed the details and problems of course contents and teaching methods[6].

In addition, from the teachers point of view, when talking about the "advantages and disadvantages of large-scale online ideological and political education", the teachers interviewed unanimously agreed that the sharing of high-quality teaching resources is the greatest advantage of large-scale online ideological and political education courses, that plays an extremely important role in promoting the quality of education, and feedback on such issues as "lack of teacher-student communication", "inadequate teaching supervision", "fragmentation of teaching content" and so on also shows that the problems considered between teachers and students are roughly the same. But from a positive point of view, many enthusiastic teachers have also put forward their own suggestions and suggestions for improving these problems. They are quite optimistic about the prospect of combining ideological and political education and teaching with information technology and also recognizes the enthusiasm, trend and reality of the combination of information technology and ideological and political education and teaching activities. At the same time, they also point out that the practice and exploration of the teaching activities of information technology and ideological and political courses, represented by large-scale online education courses, are not perfect and can not replace the traditional classroom teaching. In the process of combining ideological and political 
education and teaching with information technology, teachers of ideological and political education should combine reality, open up their thinking and actively offer advice and advice. The problems arising from the deep integration of ideological and political education and teaching activities and information technology should be found early and make up early to strengthen the timeliness of ideological and political teaching in the application of information technology.

\section{Thoughts of the development of the Integration of Information Technology and ideological and political Education and Teaching}

The integration of information technology and ideological and political education teaching activities is not only the need of technical application, but on the basis of information technology, strengthens its application in education and teaching activities, thus triggers new teaching ideas, teaching means and learning mode innovation, and realizes the deep integration and integration of the education and teaching of information technology and ideological and political courses. The deep integration of information technology and ideological and political education and teaching activities is not only the use of relevant information technology means in education and teaching activities, but also the penetration of information technology in all aspects of education and teaching activities. As a result, the traditional education and teaching mode has been changed, and the creative and spiritual teaching mode and teaching method have been spawned. Moreover, in the actual teaching activities, In order to innovate the educational concept and means of ideological and political education, we must rely on the support of information technology, which also points out the way of thinking and direction for the development of information technology in teaching and application. Combined with the above two points, it is the basic requirement of the deep integration of information technology and ideological and political education and teaching activities[7].

Application drive is an important thinking and basic strategy in the deep integration of information technology and ideological and political education and teaching activities. Focusing on the application of information technology in practical teaching activities, there are two significant changes in the teaching methods: one is that the transformation from a knowledge-based teaching method to one focused on comprehensive competence and diathesis, two is that the transformation from the teaching method with emphasis on comprehensive ability quality to that of cultivating world outlook, value view and thought view. Only on the premise of these two remarkable changes can we fully excavate the "points" of the deep integration of information technology and ideological and political education and teaching, and reflect the broad prospect and great advantages of the fusion of information technology and ideological and political education and teaching activities. The deep integration of the two is mainly reflected in the following three aspects:

\subsection{Application of Information Technology in Ideological and Political Education and Teaching.}

This refers to the current application of information technology in the two processes of "teaching" and "learning". It must be based on classroom teaching, supported by extracurricular practice and focused on solving the major problems in the reform of ideological and political education, to improve the contemporary college students learning experience and the ideological and cognitive contradictions in real life.

\subsection{The Universality of Information Technology in Classroom Teaching.}

This is not difficult to understand, that is, from the requirements of teachers and students in colleges and universities, information technology should be widely used in the classroom, and the normal teaching application should be formed under the principle of "want to use", "love to use" and "habitual use".

\subsection{Exploration and Innovation of Information Technology in the Teaching Reform of Ideological and Political Education.}

From a trend point of view, the continuous progress of information technology will inject new 
vitality into various applications, and the demand and development of ideological and political education must be relatively consistent with the progress of information technology. In order to solve the major theoretical puzzles and practical difficulties in the reform and development of ideological and political courses, we should promote the curriculum information construction, innovate and improve the teaching means and teaching methods.

\section{References}

[1] Ji Liling. Innovation research on the Innovation of ideological and political Teaching Methods in Colleges and Universities under the New Media Environment[J]. Studies in Ideological Education,2016(10):82-85.

[2] Zhang Kunjing. Investigation and Research on Informatization Teaching of Ideological and Political Theory Course in Colleges and Universities [J]. The Chinese Journal of ICT in Education,2016(16):43-45.

[3] Li Ling, Zheng Ruitao. Using information technology to improve the effectiveness of Ideological and Political Courses[J]. China Higher Education,2016(07):60-62.

[4] Wei Xiaoxi. "Internet Plus" ideological and political course: the implementation and Innovation of ideological and political course Teaching in Colleges and Universities under the Network Environment [J]. Journal of Social Science of Jiamusi University,2015,33(06):187-189.

[5] Zhu Yanhong, Zheng Bingxin. An Analysis of the effectiveness of ideological and political courses in Colleges and Universities based on the Internet[J].Journal of Shandong University of Technology(Social Sciences Edition), 2015,31(04):30-34.

[6] Wang Chengming. The present situation and Enlightenment of informational Teaching ability of ideological and political course Teachers in higher Vocational Colleges from the Perspective of MOOC[J]. Market Weekly,2015(02):120-121+9.

[7] Huang Aihua. The Reform of ideological and political Teaching Mode in Colleges and Universities in the Information Age[J]. China University Teaching,2014(09):45-49. 